\title{
Effect of Buerger's Exercises on Improving Peripheral Circulation: A Systematic Review
}

\author{
Chyong-Fang Chang 1 , Chang-Cheng Chang2, Mei-Yen Chen ${ }^{*}$ \\ ${ }^{1}$ College of Nursing, Chang Gung University of Science and Technology, Puzi City, Taiwan \\ ${ }^{2}$ Chang Gung Memorial Hospital, Puzi City, Taiwan \\ Email: meiyen@mail.cgust.edu.tw
}

Received 22 January 2015; accepted 4 February 2015; published 9 February 2015

Copyright (C) 2015 by authors and Scientific Research Publishing Inc.

This work is licensed under the Creative Commons Attribution International License (CC BY). http://creativecommons.org/licenses/by/4.0/

(c) (i) Open Access

\section{Abstract}

The aim of this study was to systematically review the evidence for the effectiveness of Buerger's exercise on the peripheral circulation or diabetic foot ulceration. A systematic search and 18 electronic databases were conducted. The intervention was predominantly focused on Buerger's exercise as an outcome. Due to high heterogeneity, data were synthesized in a narrative format rather than by statistical methods. Nine studies that covered 592 participants were selected in the analysis, of which 8 of the 9 found an effect of Buerger's exercise on peripheral circulation. The positive effects were indicative of improving blood flow, walking ability, reducing necrosis, reducing venous embolism, pain, swelling, cyanosis and the bed-rest times. However, the study design and quality appraisal were limited to Jadad score 2 and the sample size was small. Findings provide some evidence of the beneficial effects of Buerger's exercises. It was seen as a low cost and low risk physical activity that most diabetic patients could undertake at home. This review highlighted a need for further investigation of standardized procedures of Buerger's exercises. More high quality studies on the prevention of diabetic foot are required regarding Buerger's exercises.

\section{Keywords}

Buerger's Exercises, Diabetic Foot Ulceration, Lower Extremity Circulation, Systematic Review

\section{Introduction}

The global prevalence of diabetes mellitus (DM) in adults has been estimated at $8.3 \%$ in 2011 and will rise to $9.9 \%$ by 2030, affecting over 350 million individuals [1]. Diabetic foot complication is a major cause of disability, reduced quality of life, prolonged hospitalization, financial loss, lower limb amputation, and mortality rate [2]

*Corresponding author. 
[3]. People with diabetes develop foot ulcers because of neuropathy, vascular insufficiency, and impaired wound healing [4]. Nearly $90 \%$ of diabetes-related lower limb amputations were preceded by foot ulcers [5]. In addition, conventional treatments-such as operation and infection control to cure diabetic foot ulcers are often ineffective [6].

Before and after World War II, medical experts did not know how to operate or treat the patient suffering from atherosclerosis or vessel occlusion, as well as stiffening in their peripheral arteries. Some medical genius at that time developed postural treatment to improve circulation in the lower extremities [7]-[12]. Buerger's exercises or Buerger-Allen exercises were proposed by Leo Buerger [11] and modified by Arthur Allen [7]. The value of these exercises had frequently been emphasized by Allen, and many medical experts considered them as important adjuvant treatment and postoperative care for circulatory disturbances in the extremities [8] [13] [14].

The mechanism of Buerger's exercises use gravitational changes in positions that are applied to the smooth musculature of vessels and to the vascular [15]. Gravity helps alternately to empty and fill blood columns, which can eventually increase transportation of blood through them [16]. The exercises involve the individual lying flat in bed with the legs elevated at 45 degrees until blanching occurs or for a maximum of 2 minutes. The patient then sits on the edge of the bed with the feet hanging down. Further exercises include dorsiflex, plantarflex, then inward and outward movement of the feet, followed by flexing and extending of the toes. This second phase is maintained for a minimum of 2 minutes or until rubor has appeared. Finally, the individual lies supine with the feet covered with a warm blanket lasting 5 minutes. The whole cycle is repeated 3 to 6 times each session, and the complete sequence is repeated 2 - 4 times a day [1] [17].

Buerger's exercise has been included in nursing textbooks for the chapter on arterial occlusive disease for decades. It has been considered as a strategy for improving lower limbs circulation. However, lack of evidencedbased studies to support. It was recognized that they might increase the rate of blood flow, clear away stagnant blood and help establish collateral circulation to the ischemic area [18] [19]. Bottomley [17] and Ventura [20] stated that instructing a patient or his/her family about Buerger's exercises can prevent and treat diabetic foot problems, shortened any period of hospitalization, and delayed morbidity [13] [21]. Furthermore, several reports support the beneficial effects of Buerger's exercises in patients with diabetic foot problems [10] [20]. These effects are due to improving neuropathy, infection, pain, and arteriosclerosis with or without gangrene [12] [22]. However, Buerger's exercises gradually have been dropped in recent decades, and few studies have investigated the evidence-based effect on diabetes care [23]. These phenomena might be due to lack of evidence, the changing healthcare payment system focus on medical oriented reimbursement, and/or neglect of the prevention the diabetic foot by our nursing staff. Preventing diabetic foot is a critical issue worldwide. Buerger's exercises are seen as a conservative treatment of the peripheral vascular disease, low cost and low risk physical activity that most diabetes patients could undertake at home [17] [23] [24]. Therefore, the objective of this study was to systematically review the evidence for the effectiveness of Buerger's exercise on the peripheral circulation or diabetic foot ulceration.

\section{Methods}

\subsection{Search Strategy}

Over 18 of English and Chinese electronic databases from 1937 to March, 2013, were used and different terms (e.g. Buerger's exercise, Buerger-Allen exercise) were involved to search for relevant articles (Table 1). We also searched references with relevance in Google Scholar in all fields (no title or abstract restrictions) to filter the retrieved references. This was to ensure the search strategy was wide enough to recover all studies potentially relevant for the review. Studies of reference lists that seemed relevant were assessed based on the information provided in the title. The Cochrane Library search retrieved no systematic reviews.

\subsection{Study Criteria}

Two reviewers independently screened the full text of the references selected that could not initially be excluded based on their titles and abstracts. To obtain as many relevant reports as possible, broad inclusion criteria were adopted: 1) Intervention studies, those focused on Buerger's exercises. 2) Papers published in English and Chinese. The selection was not restricted by methodological quality, population and outcomes. Electronic search results were downloaded into the End Note bibliographic program, from which duplicates were deleted. 
Table 1. Search strategy.

English database

- $\quad$ Age Line (1978-March 2012).

- CINAHL Plus with Full Text (1937-March 2012).

- Cochrane Library (1966-March 2012).

- MEDLINE (1966-March 2012).

- $\quad$ OVID (1966-March 2012).

- $\quad$ ProQuest Nursing and Allied Health Source (1986-March 2012).

- $\quad$ ProQuest Health \& Medical Complete (1994-March 2012).

- $\quad$ PubMed (1966-March 2012).

- $\quad$ Science Direct (1995-March 2012).

- $\quad$ Springer Link (1990-March 2012).

Chinese database (Traditional)

- $\quad$ Chinese Electronic Periodical Services (CEPS) (1991-March 2012).

- Nation Central Library (NCL) (1970-March 2012).

- National Digital Library of Theses and Dissertations (NDLTD) (1956-March 2012).

Chinese database (Simplified)

- $\quad$ China Doctor Dissertation Full-text Database (CDFD) (1999-March 2012).

- $\quad$ China Master Theses Full-text Database (CMTD) (1999-March 2012).

- China National Knowledge Infrastructure (CNKI) (1979-March 2012).

- China Yearbook Full-text Database (CYFD) (1912-March 2012).

- Wan Fang Data (1997-March 2012).

Website

- Google Scholar.
Search terms used

- Buerger's exercises, Buerger-Allen exercises, Buerger.

- Used different terms in Chinese traditional text for Buerger's exercises.

- Used different terms in Chinese simplified text for Buerger's exercises.

\subsection{Data Extraction}

One reviewer extracted data from included studies about first author; year of publication; country of study; location; duration of study; sample; population characteristics; variable; outcome measures; quality indicators; interventions; characteristics of interventions and results. The second reviewer checked the accuracy of the extracted data.

\subsection{Quality Appraisal}

Two reviewers independently assessed the eligibility of the study, quality appraisal and carried out the analysis. The quality appraisal of the included studies was assessed using criteria based on the Jadad scale [25]. The quality questions checked were the following: 1 ) Was the study described as randomized? 2) Was the study described as double blind? 3) Was there a description of withdrawals and dropouts? 4) Was the method to generate the sequence of randomization described and it was appropriate? 5) Was the method of double blinding described and it was appropriate? 6) Was the method to generate the sequence of randomization described and it was inappropriate? 7) Was the study described as double blind but the method of blinding was inappropriate?

The methodological quality of included studies was evaluated by two reviewers. The $1-5$ questions were scored as "Yes" (1), "No" (0), and 6 - 7 were scored deduct 1 point if as "Yes". Therefore, each study could score 0 to 5 . Disagreements between the two reviewers were resolved by discussed until consensus.

\subsection{Data Synthesis}

The participants, intervention, study design, outcomes, measures and intervention characteristics were summarized with a narrative and tabular synthesis. The limited data and use of divergent variables within the studies did not allow meta-analysis.

\section{Results}

\subsection{Study Search}

A total of 95 potentially relevant papers were identified, of which 15 articles were identified by the systematic search in electronic database, and 79 papers were selected from the Google Scholar Website. One further study 
was found from a reference list. There were 86 papers that failed to reach our selection criteria, which left on 9 that could be included in the final review (Figure 1).

\subsection{Study Characteristics}

Table 2 showed that of the 9 studies reviewed, 6 randomized were controlled trials, two were pre-test studies with control group, and one was a prospective control study. Three of the studies were published before 1996 and 6 after 2005. Six of the studies were conducted in Mainland China, with one study each from Denmark, the United States and Taiwan. Five studies were lead by registered nurses, 3 by medical doctors and one by a physical therapist. Three papers were published in English [23] [26] [27] and 6 in Simplified Chinese [28]-[33]. These studies were conducted in a variety of settings, including vascular clinics, surgical, Chinese medicine, orthopedic, and gynecology units.

\subsection{Participant Characteristics}

The 9 studies involved a total of 592 participants; most of whom were hospitalized patients (66.7\%). Four of the studies patients were related to peripheral arterial occlusive disease (PAOD), 4 to orthopedics, and 1 to a gynecology problem. Two of the studies included diabetic patients [23] [26]. Sample size ranged from 14 [26] to 233 [31]. All studies did not calculate the sample size (power) required to see an effect. Seven studies gave the range age of participants from 10 to 83 years. Five studies recruited both male and female participants, but 2 did not mention gender. Only 2 studies mentioned informed consent and one study reported a drop-out rate [23] [26].

\subsection{Measurement}

Measurement variances of the selected studies were to assess Buerger's exercises with regard to several physiological outcomes or clinical symptoms. The variables of physiological indicators included Na [24] clearance rate (Geiger counter); ${ }^{133} \mathrm{Xe}$ washout rate (NaI scintillation detector); blood flux (DRT4 Laser Doppler); walking time (treadmill); skin temperature (DRT4 Laser Doppler); hemorheology (packed cell volume, fibrinogen); and bed-rest times (days). Clinical symptoms that were measured included foot necrosis (years); degree of swelling; pain (Wong-Baker Faces Pain Rating Scale, Numeric Pain Rating Scale), and degree of cyanosis (Table 2). Most of the select studies did not investigate or report on the reliability, stability and validity of their instruments. Even when using the observational study design, 5 studies did not include an operational definition, observer training and inter-rate reliability [28]-[31] [33].

\subsection{Intervention Characteristics}

All the studies had 2 intervention and comparison groups. Six of the 9 studies assessed the benefit of Buerger's exercises compared with usual care, and one compared them with arterial reconstruction [26]. Two compared the same intervention, but used different participant characteristics (Table 3) [23] [27]. Two studies had certified

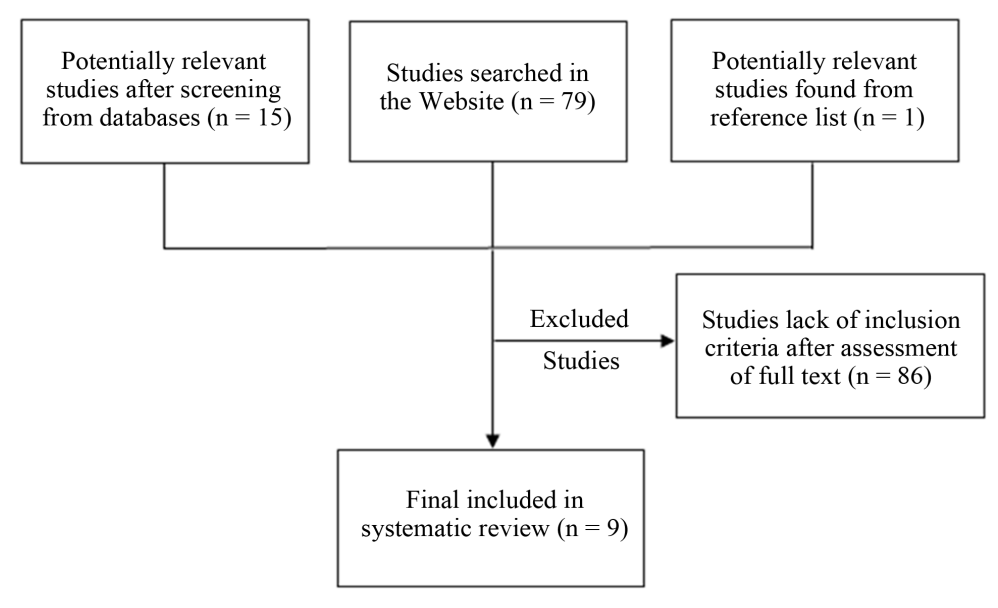

Figure 1. Flowchart of the inclusion process. 
Table 2. Characteristics of the main results.

\begin{tabular}{|c|c|c|c|c|}
\hline $1^{\text {st }}$ author and title & e Country, study design, setting, and sample sizes & Design & Outcomes & Results \\
\hline $\begin{array}{l}\text { Wisham } \\
\text { (1953) MD }\end{array}$ & $\begin{array}{l}\text { USA, } N=29 \text {, arterial disease of lower } \\
\text { extremities patients, intermittent claudication } \\
\text { of varying degree but no gangrene, at } \\
\text { vascular clinic. }\end{array}$ & $\begin{array}{l}\text { Pre-post } \\
\text { control } \\
\text { group }\end{array}$ & $\begin{array}{l}\text { Blood flow }\left(\mathrm{Na}^{24}\right. \\
\text { clearance rate }(\%)\end{array}$ & $\begin{array}{l}\text { EG: } \uparrow 17 \%-84 \% \text {, } \\
\text { CG: } \uparrow 33 \%-114 \%\end{array}$ \\
\hline $\begin{array}{l}\text { Bjerre-Jepsen } \\
\text { (1984) MD }\end{array}$ & $\begin{array}{l}\text { Denmark, } N=14 \text {, severe leg ischemia due to } \\
\text { occlusive arterial disease; All patients had } \\
\text { severe rest pain, at surgery unit }\end{array}$ & $\begin{array}{l}\text { Design: RCT, } \\
\text { pre-post }\end{array}$ & $\begin{array}{l}\text { Subcutaneous blood } \\
\text { flow }\left({ }^{133} \mathrm{Xe} \text { washout rate) }\right. \\
\text { Measures: NaI (Te) }\end{array}$ & NS \\
\hline $\begin{array}{l}\text { Wu (1996) } \\
\text { PT }\end{array}$ & $\begin{array}{l}\text { Taiwan, } N=30 \text {, peripheral arterial } \\
\text { insufficiency patients, } 18 \text { patients had } \\
\text { ulceration and/or gangrene, at vascular clinic }\end{array}$ & $\begin{array}{l}\text { Pre-post } \\
\text { control } \\
\text { group }\end{array}$ & $\begin{array}{l}\text { Skin temperature, blood } \\
\text { flux, walking time }\end{array}$ & $\begin{array}{l}\text { Blood flux }(p<0.05) \\
\text { walking time }(p<0.05)\end{array}$ \\
\hline $\begin{array}{l}\text { Fan (2005) } \\
\text { MD }\end{array}$ & $\begin{array}{l}\text { China, } N=60 \text {, arteriosclerosis obliterans } \\
\text { patients, at medicine unit }\end{array}$ & $\begin{array}{l}\text { Prospective } \\
\text { control group }\end{array}$ & Foot necrosis periods & $\begin{array}{l}\text { Foot necrosis periods } \\
(p<0.01)\end{array}$ \\
\hline $\begin{array}{l}\text { Ou (2006) } \\
\text { RN }\end{array}$ & $\begin{array}{l}\text { China, } N=233 \text {, Gynecology patients } \\
\text { postoperative, at gynecology unit }\end{array}$ & $\begin{array}{l}\text { Design: RCT, } \\
\text { post }\end{array}$ & $\begin{array}{l}\text { Hemorheology, } \\
\text { swelling, pain }\end{array}$ & Hemorheology $(p<0.01)$ \\
\hline $\begin{array}{l}\text { Zhu (2006) } \\
\text { RN }\end{array}$ & $\begin{array}{l}\text { China, } N=96 \text {, low limb trauma patients, } \\
\text { at orthopedic unit }\end{array}$ & $\begin{array}{l}\text { Design: RCT, } \\
\text { post }\end{array}$ & $\begin{array}{l}\text { Pain, swelling, } \\
\text { cyanosis, bed rest }\end{array}$ & $\begin{array}{l}\text { Pain }(p<0.01) \text {, swelling } \\
(p<0.01) \text {, cyanosis }(p<0.01) \\
\text { bed rest times }(p<0.05)\end{array}$ \\
\hline $\begin{array}{l}\text { Guan (2007) } \\
\text { RN }\end{array}$ & $\begin{array}{l}\text { China, } \mathrm{N}=30 \text {, above knee fracture after } \\
\text { internal fixation patients, at orthopedic unit }\end{array}$ & $\begin{array}{l}\text { Design: RCT, } \\
\text { post }\end{array}$ & Pain, cyanosis, swelling & $\begin{array}{l}\text { Pain }(p<0.005) \text {, cyanosis } \\
(p<0.005) \text {, swelling } \\
(p<0.005)\end{array}$ \\
\hline $\begin{array}{l}\text { Jiang (2009) } \\
\text { RN }\end{array}$ & $\begin{array}{l}\text { China, } N=60 \text {, lower limb fractures } \\
\text { patients post-surgery, at orthopedic unit }\end{array}$ & $\begin{array}{l}\text { RCT, } \\
\text { pre-post }\end{array}$ & Pain, swelling & $\begin{array}{l}\text { Pain }(p<0.01) \text {, swelling } \\
(p<0.01)\end{array}$ \\
\hline $\begin{array}{l}\text { Zhang (2009) } \\
\text { RN }\end{array}$ & $\begin{array}{l}\text { China, } \mathrm{N}=40 \text {, multiple fractures patients in } \\
\text { low extremities after internal fixation, } \\
\text { at orthopedic unit }\end{array}$ & RCT, post & $\begin{array}{l}\text { Hemorheology, }{ }^{*} \mathrm{HBV} \text {, } \\
\text { LBV, PCV }\end{array}$ & $\begin{array}{l}\text { After surgery } 14^{\text {th }}, 21^{\text {st }} \text { and } \\
28^{\text {th }} \text { day }(p<0.05, p<0.01 \\
p<0.001)\end{array}$ \\
\hline
\end{tabular}

*HBV = high blood viscosity, LBV = low blood viscosity, PCV = packed cell volume, EG = experimental group, CG = control group, NS = not significant.

nurse as intervener, one a physiotherapist. Most of the studies did not mention the background of interveners (Table 3).

The intervention time (period) of the 4 selected studies ranged from 3 - 14 days, 3 ranging from 28 days to one month. The 9 studies contained a divergent range of exercising programs, such as intensity, duration, frequency and procedure. Most of the exercises were undertaken each day $(n=6)$, the intensity ranging from $2-4$ sections a day, with each section repeated 3 - 10 times. Regarding the duration for each step, 6 studies used 1 -3 minutes and 3 used 1 - 5 minutes. Most of the procedures of Buerger's exercises were inconsistent, e.g., the angle of legs, duration of each step and each section.

\subsection{Outcomes}

Most of the studies $(\mathrm{N}=8)$ reported a positive effect of Buerger's exercises. Only one study showed no significant effect on PAOD patients [26]. More than half of the studies indicated significantly improved blood flow of the lower extremities and walking ability $(p<0.05)$, decreased hemorheology indices after operation $(p<0.05)$, reduced bed-rest times $(p<0.05)$. Six studies indicated that the exercises significantly reducing swelling, cyanosis and pain $(p<0.001)$ [29] [30] [33], reduced venous embolism $(p<0.001)$ [31] [32], and delayed the occurrence of foot ulcers and gangrene [28]. There was no significant effect on skin temperature [23].

\subsection{Quality Assessment}

Total Jadad quality score among the 9 studies ranged from 0 to 2 (Table 4). They scored less than or equal to 2 points, including 4 studies of 0 point, 4 studies of 1 point and 1 study of 2 . While 6 studies used randomized 
Table 3. Characteristics of the Buerger’s exercises.

\begin{tabular}{|c|c|c|c|c|}
\hline Author/year & Length & Angle/degree & Intensity/frequency & Procedure and duration (minutes) \\
\hline $\begin{array}{l}\text { Wisham } \\
\text { (1953) }\end{array}$ & Unclear & 60 & $6,1-5 / \mathrm{NA}$ & $\begin{array}{l}\text { Passive: Supine, leg elevated (2) } \rightarrow \text { sit, feet lowered }(3) \rightarrow \text { supine }(5) \\
\text { Active: Supine, leg elevated and movement feet }(30 \text { times a min) } \rightarrow \\
\text { sit, feet lowered and movement feet ( } 30 \text { times a min) } \rightarrow \text { supine }(5) \\
\text { Resistance: Supine, resistance to active plantar flexion ( } 30 \text { times } \\
\text { a min for } 20 \text { min) }\end{array}$ \\
\hline $\begin{array}{l}\text { Bjerre-Jepsen } \\
\text { (1984) }\end{array}$ & 5 days & $60-90$ & $\begin{array}{l}5-6,3 / 1-3 / 3 \text { cycle } \\
\text { a day for } 5 \text { days }\end{array}$ & Supine, leg elevated (1) $\rightarrow$ sit, feet lowered (1-2) $\rightarrow$ supine (3) \\
\hline Wu (1996) & 1month & $45-60$ & $\begin{array}{l}\text { 3, 2/1-5/5-7 days } \\
\text { per week }\end{array}$ & $\begin{array}{l}\text { Supine, leg elevated (1-3) } \rightarrow \text { sit, feet lowered and movement feet } \\
\text { and toe (3) } \rightarrow \text { supine (5) }\end{array}$ \\
\hline Fan (2005) & $\begin{array}{l}\text { Follow-up until } \\
\text { feet necrosis }\end{array}$ & 45 & $\begin{array}{l}5,3 / 1-5 / 7 \text { days } \\
\text { per week }\end{array}$ & $\begin{array}{l}\text { Supine, leg elevated (1-2) } \rightarrow \text { sit, feet lowered and movement feet } \\
\text { and toe (5) } \rightarrow \text { supine, leg elevated (2) }\end{array}$ \\
\hline Ou (2006) & 3 days & 45 & $\begin{array}{l}\text { Several times/1-3/ } \\
\quad \text { for } 3 \text { days }\end{array}$ & $\begin{array}{l}\text { Supine, leg elevated }(1-2) \rightarrow \text { sit, feet lowered }(2-3) \rightarrow \text { supine } \\
\text { and movement feet and toe }(2)\end{array}$ \\
\hline Zhu (2006) & 7 days & 45 & $\begin{array}{l}\text { Several times } / 1-3 / 7 \\
\text { days per week }\end{array}$ & $\begin{array}{l}\text { Supine, leg elevated }(1-2) \rightarrow \text { sit, feet lowered }(2-3) \rightarrow \text { supine } \\
\text { and movement feet and toe }(2)\end{array}$ \\
\hline Guan (2007) & 14 days & 45 & $\begin{array}{l}10,3 / 1-3 / 7 \text { days } \\
\text { per week }\end{array}$ & $\begin{array}{l}\text { Sit, feet lowered }(2-3) \rightarrow \text { supine and movement feet and toe }(2) \rightarrow \\
\text { supine, leg elevated }(1-2)\end{array}$ \\
\hline Jiang (2009) & 28 days & 45 & $\begin{array}{l}5-6,3-4 / 1-3 / 7 \\
\text { days per week }\end{array}$ & $\begin{array}{l}\text { Supine, leg elevated }(1-2) \rightarrow \text { sit, feet lowered }(2-3) \rightarrow \text { Supine } \\
\text { and movement feet and toe }(2)\end{array}$ \\
\hline Zhang (2009) & 28 days & 45 & $\begin{array}{l}\text { Several times/1-3/7 } \\
\text { days per week }\end{array}$ & $\begin{array}{l}\text { Supine, leg elevated }(1-2) \rightarrow \text { sit, feet lowered }(2-3) \rightarrow \text { Supine } \\
\text { and movement feet and toe (2) }\end{array}$ \\
\hline
\end{tabular}

Note. $\mathrm{N} / \mathrm{A}=$ not applicable, $\mathrm{N} / \mathrm{R}=$ not reported.

Table 4. Quality assessment of included studies.

\begin{tabular}{|c|c|c|c|c|c|c|c|c|}
\hline \multirow{2}{*}{ Studies } & \multicolumn{7}{|c|}{ Jadad questions } & \multirow{2}{*}{ Total score } \\
\hline & 1 & 2 & 3 & 4 & 5 & 6 & 7 & \\
\hline Wisham (1953) & 0 & 0 & 0 & 0 & 0 & 0 & 0 & 0 \\
\hline Bjerre-Jepsen (1984) & 1 & 0 & 0 & 0 & 0 & 0 & 0 & 1 \\
\hline Wu (1996) & 0 & 0 & 0 & 0 & 0 & 0 & 0 & 0 \\
\hline Fan (2005) & 0 & 0 & 0 & 0 & 0 & 0 & 0 & 0 \\
\hline Ou (2006) & 1 & 0 & 0 & 0 & 0 & 0 & 0 & 1 \\
\hline Zhu (2006) & 1 & 0 & 0 & 0 & 0 & 0 & 0 & 1 \\
\hline Guan (2007) & 1 & 0 & 0 & 0 & 0 & 0 & 0 & 1 \\
\hline Jiang (2009) & 1 & 0 & 0 & 0 & 0 & -1 & 0 & 0 \\
\hline Zhang (2009) & 1 & 0 & 0 & 1 & 0 & 0 & 0 & 2 \\
\hline
\end{tabular}

controlled trials, only 2 gave their method of randomization. One of these studies used table random numbers generated by a Stochastic [32]. One enrolled subjects according to their admission order, and was deducted 1 point. One study had withdrawal numbers, but no reason was given.

\section{Discussion}

This systematic review of the value of Buerger's exercises in improving peripheral circulation selected 9 studies, 
with most of the participants of PAOD and having orthopedic problems. In general, the results suggest that this conservative treatment positively influences blood flow, walking ability, and venous embolism. They significantly reduced necrosis periods, pain, swelling, cyanosis, and bed-rest times.

The methodological procedures were generally of poor quality, some of which could have a bearing on the validity of the results. There were limited statistical analyses in two studies that were conducted more than 20 years ago [26] [27]. Power calculation was not used in any of the studies, and sample sizes in 2 of them were small. A small sample size can give a larger bias due to variations among the participants or, in some conditions, contribute to a positive result when the observed effect is much larger than the true difference [34]. Baseline characteristics of the participants were not compared in some studies. Although 4 studies used RCT design, and only have post-test data. Furthermore, most of the studies lacked scientific vigor, such as the validity, reliability and reproducibility of the instruments were not reported [28] [29] [31] [33]. Therefore, when the measurement errors were high, the effects of the intervention would be suspect.

Notably, the measurement variables in the 9 selected studies were somewhat different. For instance, 3 studies measured blood flow with significant improvement seen in the studies of Wisham et al. [27] and Wu and Wang [23]. The results of Bjerre-Jepsen et al. [26], however, did not show improve although their methodology was similar to Wisham et al. [27]. The reasons might be due to 1$)$ the small sample size $(\mathrm{N}=14)$, and 2) the procedure and intervention dose was different with others in the study of Bjerre-Jepsen et al. [26], e.g. they did not use dorsiflex, plantarflex, then inward and outward of the feet. Theoretically, when circulation increases in a limb, an increase in its skin temperature would be expected [19]. However, the Wu and Wang [23] reported no significant differences.

Regarding procedures, most of the included studies preferred elevation of the leg at 45 degrees $(\mathrm{N}=7), 5$ - 6 times/per section $(\mathrm{N}=4), 3$ sections/per day $(\mathrm{N}=4)$, for 1 - 3 min/each duration $(\mathrm{N}=6)$. However, many studies did not state their standardized of procedures [31]-[33]. Further study is necessary to establish the standardized of procedures for Buerger's exercises.

\subsection{Strengths and Weakness}

Despite some limitations in this study, we were able to make decisions about the strength and consistency of the evidence. To the best of our knowledge, our review is the first attempt to synthesize the evidence that Buerger's exercises improve peripheral circulation. The results may be biased by only screening publications in the English or Chinese; thus, important studies might have been missed. The reviewed studies varied in participants, interventions, samples, methods, measures, and outcomes, giving a heterogeneity that disallowed meta-analysis, making comparisons between them difficult.

\subsection{Implications for Practice and Research}

Some literatures indicate that many diabetic patients apparently had foot ulcer before their lower extremities were amputated [5] [35]. Hence, providing further diabetic care with Buerger's exercises would be beneficial for diabetic patients who have peripheral circulation insufficiency or peripheral neurovasculopathy, e.g. ankle brachial pressure index $<0.9$ or Michigan Neuropath Screening Index $>2$. Therefore, it is necessary to investigate the effect of Buerger's exercises on diabetic-related peripheral disorder through evidence-based studies. Regarding the ethical consideration, only 2 studies mentioned informed consent [23] [26]. Notably, in more than half of the selected studies, the primary researchers and background of interveners were nurses, which implied that Buerger's exercises can be an important independent role for nurses to take care of hospitalized and community clients with lower extremity circulation disorders. However, the effect of Buerger's exercises and the standardization of the procedures involved ought to be subject to further more rigorous scientific researches.

\section{Conclusion}

Although most of the selected studies were not focused on diabetic foot patients, this review has found that Buerger's exercises can benefits for PAOD patients, post-operative patients with orthopedic and gynecology problems by improving local circulation, despite the studies having methodology limitations. We have found that some of the accumulated evidence supports the benefits of Buerger's exercises. It also suggests that Buerger's exercises could be an alternative procedure on improving peripheral circulation, but the need for further in- 
vestigation of optimal procedure of Buerger's exercises have been highlighted, particularly with high quality studies with optimized standard procedures being used.

\section{Competing Interests}

The authors hereby declare that there were no competing interests.

\section{Author's Contribution}

CFC, CCC and MYC designed the study conception and wrote the manuscript. All authors contributed to manuscript development, and read and approved the final manuscript.

\section{References}

[1] International Diabetes Federation (IDF) (2013) The Global Burden. http://www.idf.org/diabetesatlas/5e/the-global-burden.

[2] Boulton, A.J.M., Vileikyte, L., Ragnarson-Tennvall, G. and Apelqvist, J. (2005) The Global Burden of Diabetic Foot Disease. Lancet, 366, 1719-1724. http://dx.doi.org/10.1016/S0140-6736(05)67698-2

[3] Health Promotion and Administration, Ministry of Health and Welfare (2014) Diabetes. http://www.hpa.gov.tw/BHPNet/Web/HealthTopic/Topic.aspx?id=201409290001

[4] Harrington, C., Zagari, M., Corea, J. and Klitenic, J. (2000) A Cost Analysis of Diabetic Lower-Extremity Ulcers. Diabetes Care, 23, 1333-1338. http://dx.doi.org/10.2337/diacare.23.9.1333

[5] Alvarsson, A., Sandgren, B., Wendel, C., Alvarsson, M. and Brismar, K. (2012) A Retrospective Analysis of Amputation Rates in Diabetic Patients: Can Lower Extremity Amputations Be Further Prevented? Cardiovascular Diabetology, 11, 1-11. http://dx.doi.org/10.1186/1475-2840-11-18

[6] Lavery, L.A. (2012) Effectiveness and Safety of Elective Surgical Procedures to Improve Wound Healing and Reduce Re-Ulceration in Diabetic Patients with Foot Ulcers. Diabetes/Metabolism Research and Reviews, 28, 60-63. http://dx.doi.org/10.1002/dmrr.2241

[7] Allen, A.W. (1930) Recent Advances in the Treatment of Circulatory Disturbances of the Extremities. Annals of Surgery, 92, 931-946.

[8] Bernheim, A.R. and London, I.M. (1937) Arteriosclerosis and Thromboangiitis Obliterans. JAMA, 108, $2102-2109$. http://dx.doi.org/10.1001/jama.1937.02780250016005

[9] Bierman, W. (1949) Physical Medicine in Peripheral Vascular Diseases. JAMA, 141, 318-320. http://dx.doi.org/10.1001/jama.1949.02910050018005

[10] Brandaleone, H., Standard, S. and Ralli, E.P. (1937) Prophylactic Foot Treatment in Patients with Diabetes Mellitus. Annals of Surgery, 105, 120-124. http://dx.doi.org/10.1097/00000658-193701000-00011

[11] Buerger, L. (1926) The Circulatory Disturbances of the Extremities. Annals of Surgery, 83, 157.

[12] McKittrick, L.S. and Pratt, T.C. (1930) The Operative Treatment of Lesions of the Lower Extremities in Diabetes Mellitus. JAMA Surgery, 21, 555-581. http://dx.doi.org/10.1001/archsurg.1930.01150160002001

[13] Edwards, L. and Crisenberry, H. (1938) Vascular Disorders of the Extremities: A Discussion of Nursing Care. American Journal of Nursing, 38, 13s-17s. http://dx.doi.org/10.2307/3414247

[14] Lloyd, J.T. (1957) Traumatic Peripheral Aneurysms. American Journal of Surgery, 93, 755-764. http://dx.doi.org/10.1016/0002-9610(57)90546-9

[15] Conti, A.A., Macchi, C., Conti, A. and Gensini, G.F. (2007) Relationship between Physical Activity and Cardiovascular Disease: Selected Historical Highlights. The Journal of Sports Medicine and Physical Fitness, 47, 84-90.

[16] Jackson, B.S. (1972) Chronic Peripheral Arterial Disease. American Journal of Nursing, 72, 928-934.

[17] Bottomley, J.M. (2007) The Insensitive Foot. In: Timothy, L.K., John, O.B. and Michael, L.M., Eds., Geriatric Rehabilitation Manual, 2nd Edition, Churchill Livingstone, Edinburgh, 333-343. http://dx.doi.org/10.1016/B978-0-443-10233-2.50058-4

[18] Sommers, M.S., Johnson, S.A. and Berry, T.A. (2007) Arterial Occlusive Disease. In: Diseases \& Disorders: A Nursing Therapeutics Manual, 3rd Edition, F.A. Davis Company, Philadelphia, 102-106.

[19] Wright, I. (1940) Conservative Treatment of Occlusive Arterial Disease. JAMA Surgery, 40, 163-189. http://dx.doi.org/10.1001/archsurg.1940.04240010003002

[20] Ventura, E. (1978) Adult Diabetes: Foot Care for Diabetics. American Journal of Nursing, 78, 886-888. 
[21] Locke, R.K. (1963) Foot Care for Diabetics. American Journal of Nursing, 63, 107-110.

[22] Jordan, W.R. (1936) Neuritic Manifestations in Diabetes Mellitus. JAMA Internal Medicine, 57, 307-366. http://dx.doi.org/10.1001/archinte.1936.00170060069004

[23] Wu, Y.T. and Wang, S.S. (1996) Effects of Buerger-Allen Exercises on Peripheral Vascular Function in Patients with Peripheral Arterial Insufficiency. National Science Council Report, Taipei, 1-15.

[24] Liu, J.Z., Zhao, Y.Z., Chen, J.H., Chen, L.X. and Liu, F. (2010) The Care of Patients with Diabetic Foot after Balloon Dilatation Operation. Hebei Medical Journal (Chinese), 32, 2296-2297.

[25] Jadad, A.R., Moore, R.A., Carroll, D., Jenkinson, C., Reynolds, D.J.M., Gavaghan, D.J., et al. (1996) Assessing the Quality of Reports of Randomized Clinical Trials: Is Blinding Necessary? Controlled Clinical Trials, 17, 1-12. http://dx.doi.org/10.1016/0197-2456(95)00134-4

[26] Bjerre-Jepsen, K., Faris, I., Henriksen, O. and Paaschburg-Nielsen, B. (1984) Effect of Therapy on 24-h Subcutaneous Blood Flow in the Leg in Patients with Severe Ischemia. European Journal of Nuclear Medicine, 9, 413-415. http://dx.doi.org/10.1007/BF00295576

[27] Wisham, L.H., Abramson, A.S. and Ebel, A. (1953) Value of Exercise in Peripheral Arterial Disease. JAMA, 153, 1012. http://dx.doi.org/10.1001/jama.1953.02940180012003

[28] Fan, Y.C. and Zhang, G.P. (2005) Effect of Buerger Exercise of Delay Gangrene for Patients with Arteriosclerosis Obliterans. Chinese Journal of Surgery of Integrated Traditional and Western Medicine (Chinese), 11, 124-125.

[29] Guan, X.L., Zhu, L.P., Huang, Y.C., Cheng, M.Y. and Liu, M.M. (2007) Effect of Buerger Exercise for Patients with Above Knee Fracture in Lower Extremities after Internal Fixation. The Journal of Medical Theory and Practice (Chinese), 20, 809-810.

[30] Jiang, W.Y., Zhang, R.H., Liu, J.J., Li, F.Y., Wang, B.Q., Chen, J. and Chen, Y. (2009) The Influence of Buerger Exercise on the Post-Surgery Swelling and Pain in Patients with Lower Limb Fractures. Journal of Nursing (Chinese), 16, 1-3.

[31] Ou, X.Q., Chen, C.F., Wang, L.L., Yu, G.Q. and Luo, W.J. (2006) Effect of Buerger Exercise for Patients with Gynecologic Tumor to Prevention of Deep Venous Thrombosis after Operation. Modern Nursing (Chinese), 12, 839-840.

[32] Zhang, R.H., Jiang, W.Y., Liu, J.J., Li, F.Y., Liu, H.E. and Zhu, C.Y. (2009) Effect of Buerger Training on Hemorheology for Patients with Multiple Fractures in Lower Extremities after Internal Fixation. Nursing and Rehabilitation Journal (Chinese), 8, 903-905.

[33] Zhu, L.P., Guan, X.L., Xiao, X.J., Huang, Y.C., Lian, M.R., Liu, M.M., et al. (2006) The Clinical Study of Buerger Training as Rehabilitation Method in Leg Trauma Patients. Chinese Journal of Practical Nursing (Chinese), 22, 6-8.

[34] Altman, D.G. (1997) Clinical Trials. In: Altman, D.G., Ed., Practical Statistics for Medical Research, Chapman \& Hall/CRC, London, 455.

[35] Chen, M.Y., Huang, W.C., Peng, Y.S., Guo, J.S., Chen, C.P., Jong, M.C. and Lin, H.C. (2011) Effectiveness of a Health Promotion Program for Farmers and Fishermen with Type 2 Diabetes in Taiwan. Journal of Advanced Nursing, 67, 2060-2067. http://dx.doi.org/10.1111/j.1365-2648.2011.05678.x 
Scientific Research Publishing (SCIRP) is one of the largest Open Access journal publishers. It is currently publishing more than 200 open access, online, peer-reviewed journals covering a wide range of academic disciplines. SCIRP serves the worldwide academic communities and contributes to the progress and application of science with its publication.

Other selected journals from SCIRP are listed as below. Submit your manuscript to us via either submit@scirp.org or Online Submission Portal.
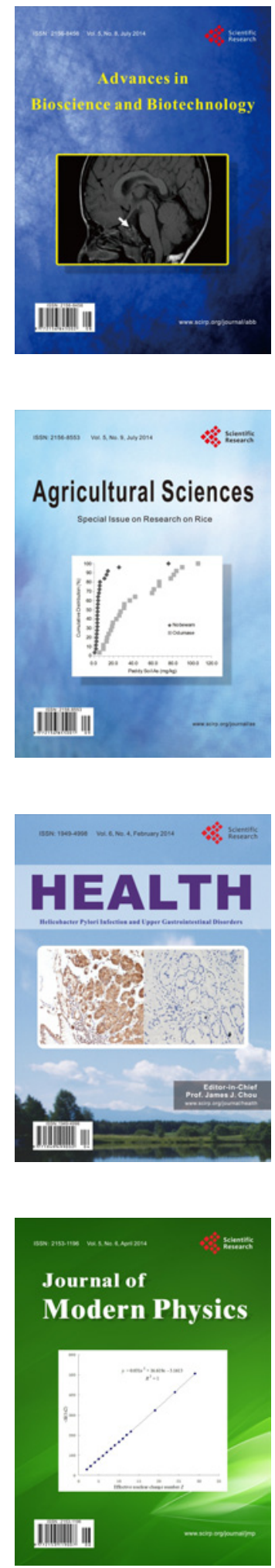
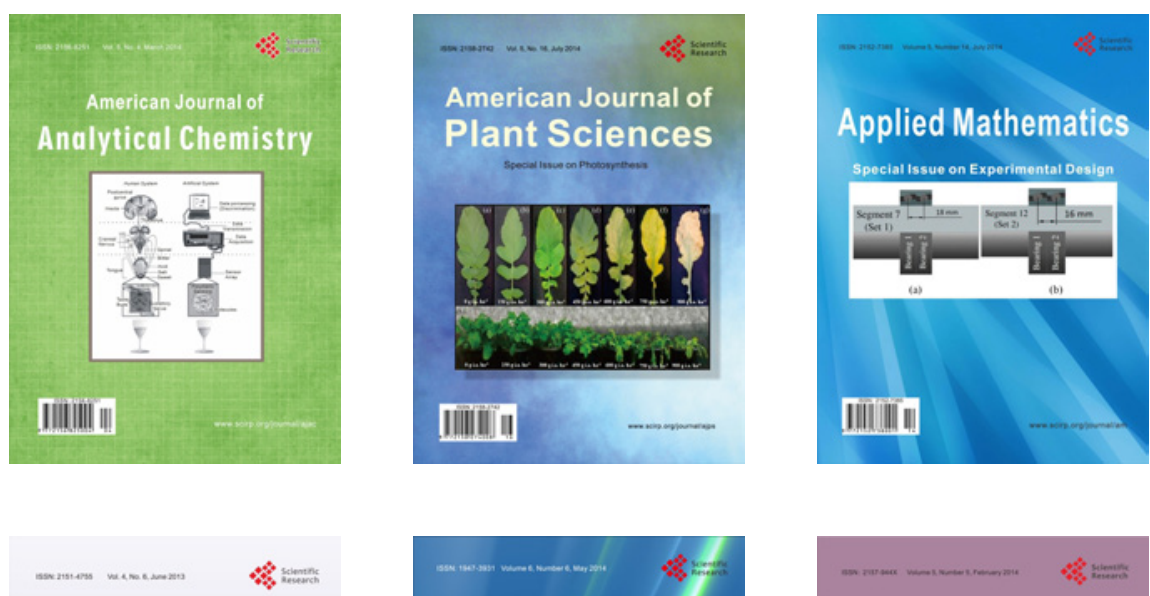

Creative Education
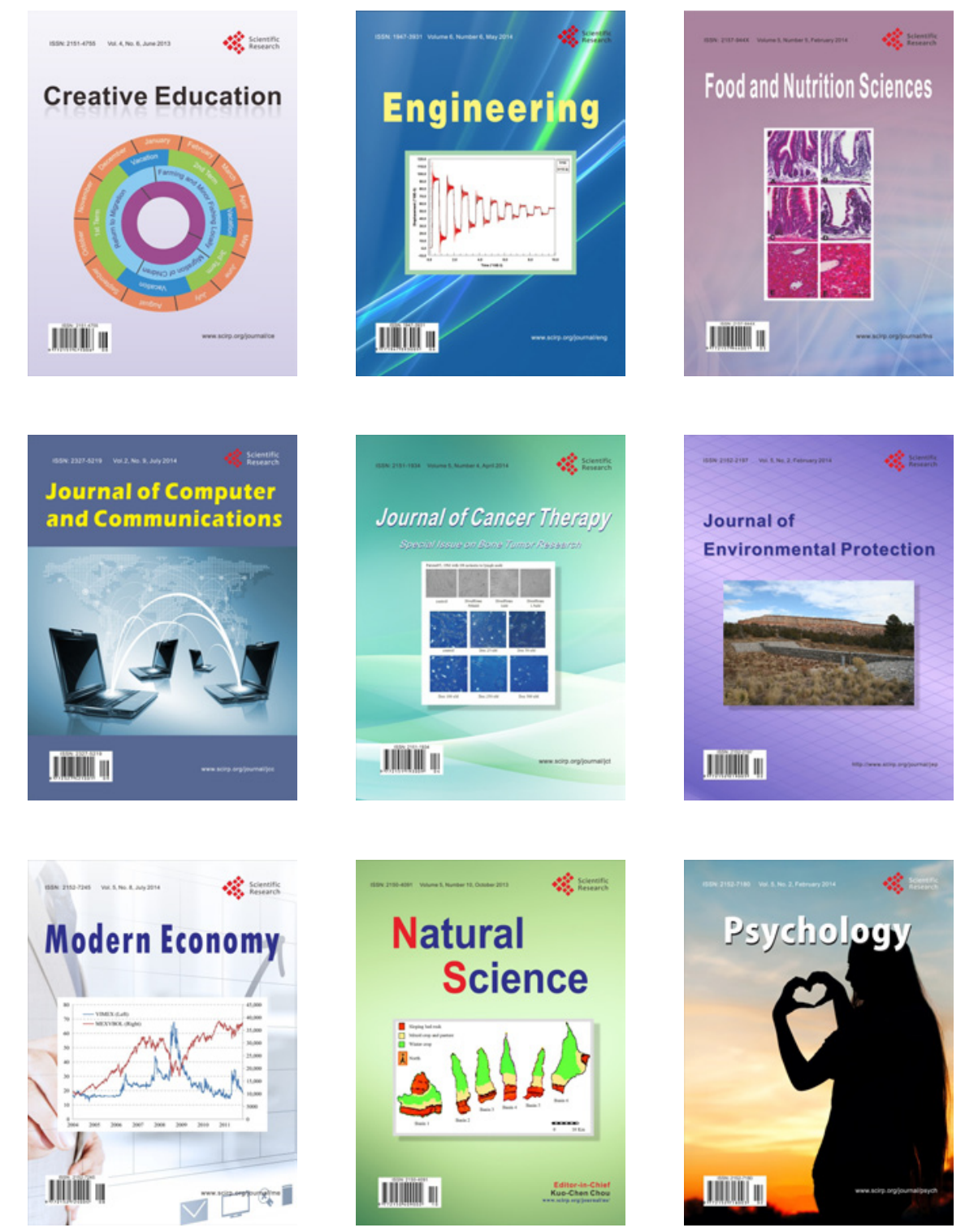